\title{
Дослідження безпосередніх та віддалених результатів комплексного лікування хворих з місцево-розповсюдженим раком молочної залози з використанням системної та ендолімфатичної поліхіміотерапії в неоад'ювантному режимі
}

\section{Ю. В. Думанський ${ }^{1}$, О. В. Бондар ${ }^{2,3}$, О. І. Ткаченко ${ }^{2}$, Є. А. Столярчук ${ }^{3}$, В. Ю. Єрмаков \\ 'Донецький національний медичний університет, м. Лиман, \\ ${ }^{2}$ Одеський національний медичний університет,

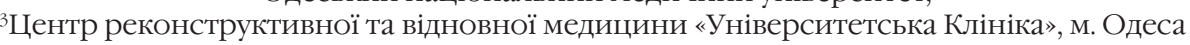 \\ Investigation of immediate and late results of complex treatment in patients, suffering locally-spread mammary gland cancer, using systemic and endolymphatic neoadjuvant polychemotherapy}

\author{
Yu. V. Dumanskyi ${ }^{1}$, O. V Bondar ${ }^{2,3}$, O. I. Tkachenko' ${ }^{2}$ E. A. Stolyarchuk ${ }^{3}$, V. Yu. Ermakov ${ }^{3}$ \\ ${ }^{1}$ Donetsk National Medical University, Lyman, \\ ${ }^{2}$ Odessa National Medical University, \\ ${ }^{3}$ Centre of reconstructive and Restoration Medicine «University Clinic», Odessa
}

\section{Реферат}

Мета. Порівняти безпосередні та віддалені результати лікування хворих з місцево-розповсюдженим раком молочної залози (МР РМЗ) з використанням різних способів введення препаратів поліхіміотерапії (ПХТ).

Матеріали і методи. Дослідження проведено на основі вибіркового аналізу медичних карт 112 стаціонарних хворих з MP PM3 стадії Т4A-DNO-3M0, які отримували комплексне протипухлинне лікування на базі Донецького обласного протипухлинного центру та Університетської клініки Одеського національного медичного університету в 2000 - 2017 рр. До контрольної групи увійшли 65 (58\%) пацієнток з неоперабельними формами МР РМЗ, яким у неоад’ювантному режимі була проведена системна ПХТ (СПХТ). До досліджуваної групи увійшли 47 (42\%) пацієнток 3 неоперабельними формами МР РМЗ, яким як неоад’ювантний курс була проведена ендолімфатична ПХТ (ЕЛПХТ).

Результати. За показниками три- та п'ятирічної виживаності між контрольною і досліджуваною групами не було статистично значущої відмінності. Безпосередні результати лікування пацієнток, яким проведена ЕЛПХТ у неоад’ювантому режимі, кращі, ніж результати лікування пацієнток, яким проведена СПХТ, без статистично значущої переваги.

Висновки. Безпосередні і віддалені результати комплексного лікування МР РМЗ у разі несприятливого прогнозу пухлинного росту з проведенням ЕЛПХТ у неоад'ювантному режимі і виконанням радикального оперативного втручання кращі в порівнянні з результатами лікування за аналогічною схемою, але з проведенням СПХТ на передопераційному етапі, без статистично значущої переваги.

Ключові слова: місцево-розповсюджений рак молочної залози; комплексне лікування; ендолімфатична поліхіміотерапія; системна поліхіміотерапія.

Abstract

Objective. To compare the immediate and late results of treatment in patients, suffering locally-spread mammary gland cancer (LSMGC), using various methods of administration of preparations for polychemotherapy (PCHTH).

Materials and methods. The investigation was conducted, basing on selective analysis of medical cards of 112 stationary patients, suffering LSMGC Stage T4A-DNO-3M0, who obtained complex antitumoral treatment on the base of the Donetsk Regional Antitumoral Centre and the University Clinic of the Odessa National medical University in $2000-2017$ yrs. Into the comparison group 65 (58\%) women-patients were included, suffering inoperable forms of a LSMGC, to whom a systemic polychemotherapy (SPCHTH) was conducted in a neoadjuvant regime. Into the investigation group 47 (42\%) women-patients were included with inoperable forms of a LCMGC, to whom, as a neoadjuvant course, endolymphatic PCHTH (EPCHTH), was conducted.

Result. In the aspect of indices of a three- and a five-year survival a statistically significant difference between the groups investigated was absent. Immediate results of the women-patients, to whom a neoadjuvant ELPCHTH was conducted, have shown no statistically significant difference with those, treated, using SPCHTH.

Conclusion. Immediate and late results of complex therapy for a LSMGC in unfavorable prognosis of tumoral growth with conduction of ELPCHTH in a neoadjuvant regime and performance of radical operative intervention are better, comparing with the treatment result in accordance to similar scheme, but with conduction of SPCHTH on a preoperative stage, without statistical significance.

Keywords: locally-spread mammary gland cancer; complex therapy; endolymphatic polychemotherapy; systemic polychemotherapy. 
Незважаючи на посилену увагу з боку вчених і практиків до питання лікування та профілактики РМЗ і виявлення даної патології, недавні статистичні дані не демонструють радикальних змін у динаміці виживаності пацієнток [1]. Очевидна неефективність стандартних підходів послужила підставою для створення принципу мультидисциплінарного підходу та етапного комплексного лікування. У контексті науково-технічного прогресу в даному напрямку закономірним став розвиток таргетной терапії $[2,3]$, в основу якої покладена штучна векторизація доступних методів лікування. Регіонарна терапія виявилась адекватним вирішенням часткового завдання оптимізації адресної доставки діючої речовини до необхідної ділянки, мета якої - сконцентрувати первинну ударну дозу введеного препарату на вогнище пухлинного росту і домогтися протекції інтактних, але потенційно сприйнятливих до хіміотерапії органів шляхом зниження системного розподілу цитотоксичних речовин $[4,5]$.

Мета дослідження: дослідити безпосередні та віддалені результати лікування хворих з МР РМЗ з використанням різних способів введення хіміотерапевтичних препаратів.

\section{Матеріали і методи дослідження}

Проведено вибірковий ретроспективний аналіз медичних карт 112 стаціонарних хворих з МР РМЗ стадії Т4АDN0-3M0, які отримували комплексне спеціалізоване лікування на базі Донецького обласного протипухлинного центру та Університетської клініки Одеського національного медичного університету в 2000 - 2017 рр.

Для дослідження обрали хворих з первинно неоперабельними формами РМЗ, для яких у рамках комплексного підходу були розроблені і застосовані індивідуальні схеми неоад'ювантної ПХТ з метою досягнення операбельного стану пухлини. Вивчали спостереження використання СПХТ та ЕЛПХТ, на підставі чого були сформовані дві групи хворих: контрольна і досліджувана.

За віковим складом, поширеністю пухлинного процесу, наявністю супутньої патології склад контрольної і досліджуваної груп був однорідним.

Всі пацієнтки були детально ознайомлені з програмою лікувально-діагностичних заходів і дали письмову добровільну інформовану згоду на даний вид лікування.

До контрольної групи включили 65 (58\%) пацієнток, яким як неоад'ювантну терапію проведено серію курсів внутрішньовенної СПХТ за схемами СMF, CAF або САМF (препарати вводили згідно з відомими схемами системно).

До досліджуваної групи включили 47 (42\%) хворих з МР РМЗ, яким як неоадювантну терапію проведено серію курсів ЕЛПХТ. Програма комплексного лікування хворих цієї групи включала методику, розроблену в Донецькому обласному протипухлинному центрі (Пат. України № 33909 від 25.07.2008 р., Бюл. № 14 «Спосіб проведення хіміотерапії у хворих на злоякісні пухлини»), яка передбачає виконання прецизійної мікрохірургічної катетеризації глибокої лімфатичної судини стегна. Для доставки розчину діючої речовини в аферентне лімфатичне русло використовували інфузійне введення за допомогою інфузомата зі швидкістю 0,3 - 0,5 мл/хв, з можливістю контролю об'ємного потоку інфузії і унеможливленням екстра- вазації. Курсову дозу препаратів вводили за вказаною методикою $з$ інтервалом у 21 день. Радикальне оперативне втручання (модифікації мастектомії) у хворих досліджуваної групи виконували тільки у разі досягнення повної або часткової відповіді пухлини. Курси ЕЛПХТ проводили в режимі безперервної тривалої інфузії (до 8 год) за схемами CMF, CAF або CAMF. 3 огляду на локальну гістотоксичність і високу ймовірність розвитку ускладнень в місці введення, інтеркалятор адріаміцин застосовували в режимі внутрішньовенного введення (схема ЕЛХПТ з внутрішньовенною асистенцією), а антиметаболіти та алкілуючі агенти (метотрексат, 5-фторурацил і циклофосфан) в усіх схемах вводили ендолімфатично.

Протокол СMF у режимі ЕЛПХТ: циклофосфан з 2-го по 4-й день 400 мг/м²; метотрексат у 1-й і 5-й день по 30 мг/м²; 5-фторурацил з 2-го по 4-й день 500 мг/м².

Протокол САF у режимі ЕЛПХТ: циклофосфан з 2-го по 4-й день 400 мг/м²; фторурацил з 2-го по 4-й день 500 мг $/ \mathrm{M}^{2}$; доксорубіцин у 1 -й день внутрішньовенно 50 мг $/ \mathrm{M}^{2}$.

Протокол САМF у режимі ЕЛПХТ: циклофосфан з 2-го по 4-й день 400 мг/м²; метотрексат у 1-й і 5-й дні по 30 мг $/ \mathrm{M}^{2}$; 5-фторурацил з 2-го по 4-й дні 500 мг/м²; доксорубіцин у 1-й день внутрішньовенно 30 мг/м².

Сумарні курсові дози діючих речовин для кожної схеми ПХТ відповідали критеріям BSA (Body Surface Area).

Кількість циклів хіміотерапії визначали на підставі таких параметрів: оцінка ефективності лікування, загальний стан пацієнток, наявність та ступінь вираженості інтоксикаційного синдрому. Переважна більшість досліджуваних хворих отримала 2 - 3 цикли ПХТ у неоад'ювантному режимі для досягнення клінічного ефекту (резектабельність пухлини).

Для характеристики ефективності терапії в процесі роботи була використана шкала RECIST (Response Evaluation Criteriain Solid Tumors). У всіх спостереженнях визначали найбільший лінійний розмір усіх вогнищ пухлинного росту, після чого вираховували сумарний комплексний параметр, який брали за основу оцінки індивідуальної клінічної динаміки.

Критерії ефективності терапії за шкалою RECIST: повна відповідь - зникнення всіх осередків ураження на термін не менше 4 тиж; частковий ефект - зменшення вогнищ на 30\% і більше; прогресування - збільшення на 20\% найменшої суми осередків ураження, зареєстроване за час спостереження, або поява нових вогнищ; стабілізація - немає зменшення, яке можна оцінити як частковий ефект, або збільшення, яке можна оцінити як прогресування.

Оцінюючи лікувальний ефект, враховували динаміку об'єктивного стану пацієнток, результати клініко-лабораторних обстежень, патоморфологічну картину (динамічна трепан-біопсія для оцінки лікувального патоморфозу пухлини після проведення ПХТ).

Клінічний перебіг захворювання та віддалені результати лікування оцінювали за такими параметрами: тривалість життя без рецидивів і нових метастазів; частота лімфогенного і гематогенного метастазування; скоригована п'ятирічна виживаність.

Зазначені показники розраховували в цілому щодо залучених до дослідження хворих і окремо щодо контроль- 
ної і досліджуваної груп у залежності від проведеного варіанта паліативного лікування.

Визначення віддалених результатів здійснювали з моменту початку лікування.

\section{Результати}

Безпосередні результати комплексного лікування досліджуваних хворих

Інтервалом для контрольного огляду пацієнток у післяопераційному періоді був обраний термін 6 міс як оптимальний.

Технічно для оцінки ефективності проведеної ПХТ використовували типові загальновідомі критерії Комітету експертів ВООЗ. Лінійною характеристикою первинного і метастатичного вогнищ вважали комплексну диференційну оцінку двох найбільших перпендикулярних вимірювань. При цьому важливим моментом було дотримання чистоти дослідження з використанням принципів наступності: дослідження проводили за допомогою відкаліброваної апаратури з однаковими характеристиками.

Після виконання курсів ПХТ у неоад'ювантному режимі системний мієлотоксичний ефект, оцінений за ступенем депресії клітин гранулоцитарного паростка (лейкопенія), спостерігали у 2 (3,08\%) пацієнток контрольної і у 2 (4,26\%) - досліджуваної групи.

У контрольній групі проведено оперативне лікування 61 (93,8\%) пацієнтці в обсязі мастектомії за Мадденом, 4 (6,2\%) - за Холстедом. У досліджуваній групі всім 47 пацієнткам виконано оперативне втручання в обсязі мастектомії за Мадденом.

За даними морфологічного дослідження матеріалу біоптатів серед хворих, які отримували СПХТ, лікувальний патоморфоз 1 ступеня констатували у 8 (12\%), 2 ступеня у 28 (43\%), 3 ступеня - у 26 (40\%), 4 ступеня - у 3 (5\%); серед хворих, які отримували ЕЛПХТ - відповідно у 4 (8,5\%), 14 (30\%), 25 (53\%) і 4 (8,5\%).

Значущими критеріями ускладненого перебігу післяопераційного періоду вважали порушення дренажної функції лімфатичної системи верхньої кінцівки (блок відтоку 2 - 3 ступеня) на стороні ураження та дисфункцію процесу репарації тканин. Лімфостаз констатували у 5 (10,5\%) пацієнток досліджуваної групи та у 8 (12,3\%) - контрольної. Загоєння післяопераційної рани вторинним натягом спостерігали у 7 (14,9\%) хворих досліджуваної групи та у 11 (16,9\%) - контрольної. У 1 (1,5\%) пацієнтки контрольної групи розвинувся крайовий некроз.

Відмінності розподілів оцінки ефективності лікування хворих контрольної та досліджуваної груп за шкалою RECIST є статистично незначущими для кожної окремо взятої групи (за ступенями патоморфозу): p-level = 0,057 у найбільшому вимірі відмінностей (13\%) - для 2 ступеня i p-level $=0,234-$ для 3 ступеня.

Віддалені результати комплексного лікування досліджуваних хворих

У 4 (8,5\%) хворих досліджуваної групи спостерігали прогресування захворювання: у 1 - віддалене метастазування в легеневу тканину (одиничне вогнище в CVI правої легені) на 6-й міс після проведеного лікування; у 1 - метастатичне ураження печінки (одиничне вогнище в сегменті V) на

\begin{tabular}{|c|c|c|c|c|}
\hline \multicolumn{5}{|c|}{ Ефективність лікування хворих } \\
\hline \multirow{3}{*}{$\begin{array}{c}\text { Ефект за шкалою } \\
\text { RECIST }\end{array}$} & \multicolumn{4}{|c|}{ Група хворих } \\
\hline & \multicolumn{2}{|c|}{ досліджувана (n=47) } & \multicolumn{2}{|c|}{ контрольна $(\mathrm{n}=65)$} \\
\hline & абс. & $\%$ & абс. & $\%$ \\
\hline Повний & 4 & 8,5 & 3 & 5 \\
\hline Частковий & 21 & 45 & 26 & 40 \\
\hline Стабілізація & 18 & 38 & 29 & 44 \\
\hline Прогресування & 4 & 8,5 & 7 & 11 \\
\hline
\end{tabular}

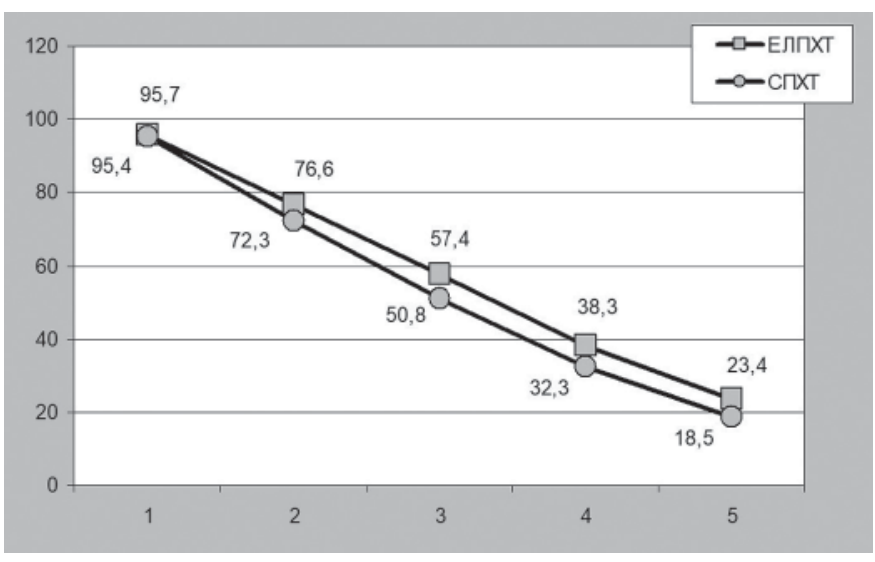

Показники виживаності хворих

13-й міс після операції; у 1 - внутрішньошкірні метастази (три верифікованих вогнища пухлинного росту в післяопераційному рубці через 2 і 2,5 міс після операціï); у 1 метастатичне ураження контралатеральних пахвових лімфатичних вузлів через 74 доби після лікування.

У процесі динамічного спостереження прогресування захворювання виявлено у 7 (11\%) пацієнток контрольної групи: у 1 - метастатичні відсівання в плевральну порожнину на стороні ураження через 4 міс після комплексного лікування; у 2 - метастази в кістки хребта (TXI-XII і TVI через 12 і 13 міс відповідно); у 2 - метастази в легені (CIV і CVII через 9 і 6 міс відповідно на іпсилатеральній стороні); у 1 - рецидив у післяопераційному рубці у вигляді одиничного вузла на 11-му міс після операції; у 1 метастази в лімфатичні вузли середостіння через 13 міс після завершення лікування (див. таблищю).

Всім пацієнткам з діагностованим прогресуванням хвороби було запропоновано індивідуальну схему психологічної допомоги та симптоматичної терапії.

\section{Обговорення}

Порівняння кривих виживаності для обох груп пацієнток (див. рисунок) показало статистично незначущі відмінності з незначною референтною та візуальною перевагою у бік ЕЛПХТ (p-level = 0,204 у разі використан-

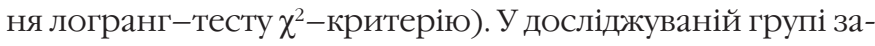
гальна три- і п'ятирічна виживаність становила відповідно $(57,4 \pm 5,3)$ і $(23,4 \pm 3,6) \%$, у контрольній - $(50,8 \pm 3,7)$ і $(18,5 \pm 5,2) \%$ відповідно.

\section{Висновки}

Результати комплексного лікування МР РМЗ з несприятливими факторами прогнозу пухлинного росту з нео- 
ад'ювантною ЕЛПХТ і виконанням радикального оперативного втручання в порівнянні з неад'ювантною СПХТ в безпосередньому і віддаленому періоді мали незначну перевагу без статистично значущої відмінності.

\section{References}

1. Howard-Anderson J, Ganz PA, Bower JE, Stanton AL. Quality of Life, Fertility Concerns, and Behavioral Health Outcomes in Younger Breast Cancer Survivors: A Systematic Review. NCI: Journal of the National Cancer Institute. 2012 March. 104(5): 386-405. doi:10.1093/jnci/djr541.

2. De Santis C, Ma J, Bryan L, Jemal A. Breast cancer statistics CA Cancer J Clin. 2014 Jan-Feb;64(1):52-62. doi:10.3322/caac.21203.
3. Liu L, Fiorentino L, Rissling M, Natarajan L, Parker BA, Dimsdale JE, et. al. Decreased Health-Related Quality of Life in Women With Breast Cancer Is Associated With Poor Sleep. Behavioral Sleep Medicine. 2013. 11 (3): 189-206. doi:10.1080/15402002.2012.660589.

4. Sharma N, Purkayastha A. Factors Affecting Quality of Life in Breast Cancer Patients: A Descriptive and Cross-sectional Study with Review of Literature. J Mid-life Health. April/June 2017. 8(2): 75-83. doi: 10.4103/jmh.JMH_15_17.

5. Eom CS, Shin DW, Kim SY, Yang HK, Jo HS, Kweon SS, et al. Impact of perceived social support on the mental health and health-related quality of life in cancer patients: Results from a nationwide, multicenter survey in South Korea. Psychooncology. June 2013. 22 (6): 1283-1290. doi: $10.1002 /$ pon.3133.

\title{
Вельмишановні колеги! Запрошуємо Вас прийняти участь у щорічній науково-практичній конференції з міжнародною участю АКТУААЬНІ ПИТАННЯ НЕВIАКАААНОї ХІРУРГIї, яка віАбудеться \\ 4-5 квітня 2019 року \\ у м. Харкові \\ (ПосвіАчення УкрНTI № 473 віА 8 жовтня 2018 року).
}

\author{
На обговорення виносяться такі питання: \\ Хірургія органів грудної та черевної порожнини \\ Хірургія ушкоАжень та їх усклаАнень \\ Мініінвазивні технології у сучасній хірургії \\ Новітні технології в хірургії
}

Вимоги Ао оформлення матеріалів:

Матеріали статей обсягом 7-12 сторінок (з урахуванням резюме та переліку літератури) будуть опубліковані в журналі “Харківська хірургічна школа", що віАповідає вимогам ААК України, тези обсягом до 3 стор. та статті, які не віАповіАають вимогам, журналу будуть налруковані в збірнику "Хірургічна перспектива", який не входить до переліку фахових видань.

Стаття повинна містити віАомості про авторів - прізвище, ім'я, по батькові, посада, науковий ступінь або вчене звання автора, поштова аАреса, індекс, контактний телефон, електронна аАреса.

ВіА одного автора надсилати не більш 2 робіт.

Вартість публікації сторінки Арукованого тексту - 50 грн.

Матеріали просимо наАсилати Ао 15 лютого 2019 року на електронну алресу conference-ionx@i.ua Телефони Аля АовіАок (057) 349-41-39, 349-41-05, або +380503025657 - Береснєв Сергій Олександрович.

Матеріали, що надійшли після вказаного терміну в разі вк^ючення Аоповідей в програму конференції, будуть надруковані в наступних номерах видань. 